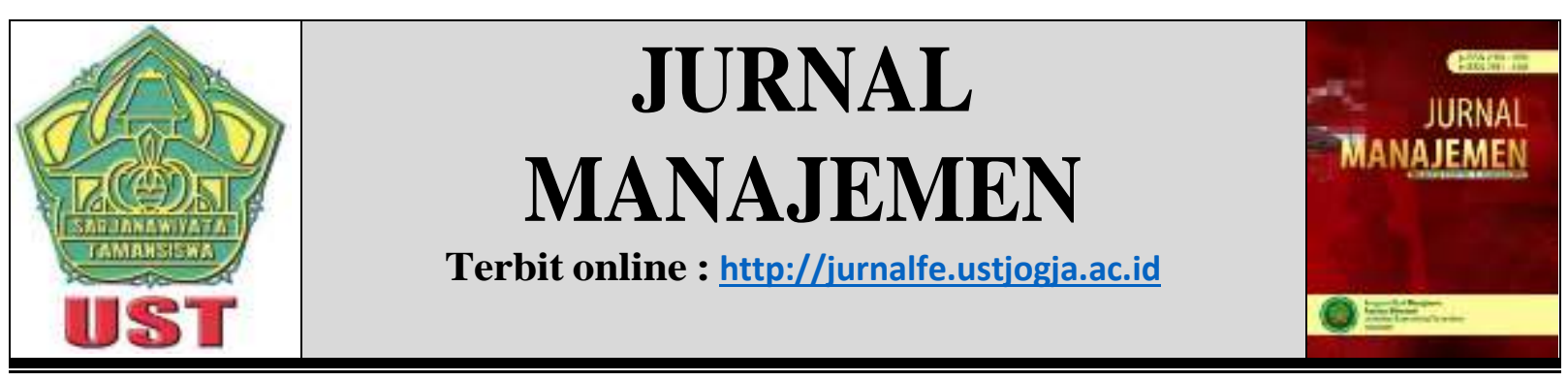

\title{
ANALISIS PROSES KERJA PENGELUARAN SPARE PART INDUSTRI MANUFAKTUR
}

\author{
${ }^{1}$ Yevita Nursyanti, ${ }^{2}$ Siti Dhetia \\ ${ }^{1,2}$ Manajemen Logistik Industri Elektronika, Politeknik APP Jakarta \\ E-mail: yevita.nursyanti@gmail.com
}

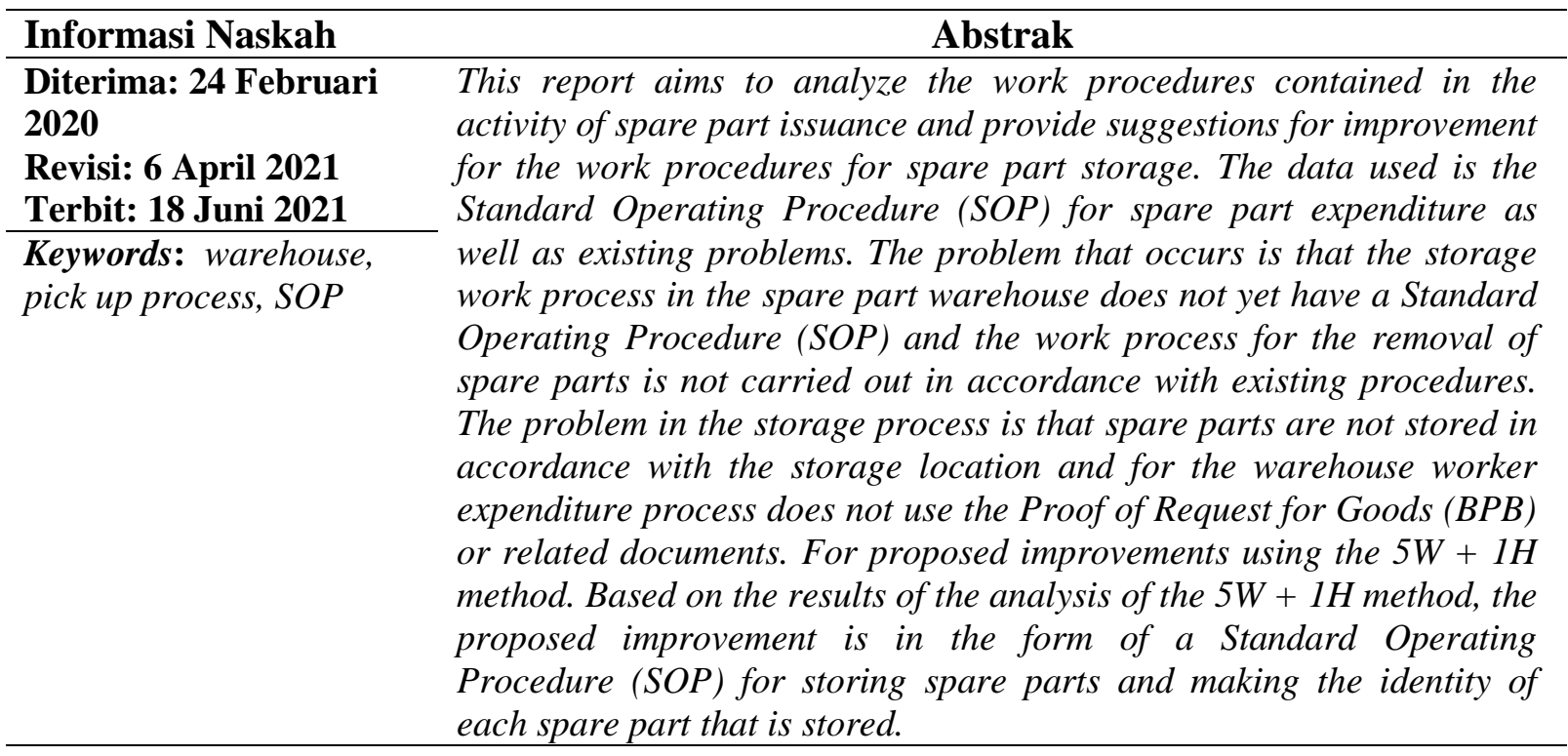

\section{PENDAHULUAN}

Spare part yang disimpan ada tiga jenis atau type, yang pertama ialah consumable part, jenis ini merupakan spare part yang habis pakai dan rutin digunakan. Jenis critical part merupakan spare part yang tidak rutin digunakan tetapi harus memiliki stock di gudang karena sangat berpengaruh terhadap mesin produksi dan yang ketiga ialah commont part jenis ini merupakan spare part yang digunakan hanya saat ada keperluan proyek saja. Gudang spare part memegang peranan penting dalam menjaga kehandalan mesin produksi, selain itu gudang spare part juga mengelola produk yang berisi cairan kimia yang digunakan untuk proses produksi dan bagian quality control. Setelah melakukan observasi pada divisi gudang spare part dapat diketahui bahwa terjadi perbedaan antara jumlah stock spare part aktual dengan stock data pada sistem saat kegiatan stock opname atau stock take. Hal tersebut disebabkan karena kegiatan kerja aktual dengan SOP yang sudah ditetapkan oleh perusahaan tidak dilakukan sesuai dengan prosedur. Seperti saat pengeluaran spare part, user yang bekerja tidak menggunakan form BPB (Bukti Permintaan barang) atau user tidak menggunakan dokumen TJO 
(Technical Job Order) dan untuk proses penyimpanan spare part tidak disimpan sesuai dengan lokasi penyimpanan, hal tersebut disebabkan karena untuk proses penyimpanan di gudang spare part belum memiliki Standard Operating Procedure (SOP).

Menurut Fatimah, Fajar Nuraini (2014) Standard Operating Procedure atau disingkat SOP biasanya dijadikan standar bagi pelaksanaan prosedur kerja tertentu. Sehingga banyak juga yang menyebutnya sebagai "prosedur" diartikan sebagai tahap kegiatan untuk menyelesaikan suatu aktivitas, atau metode langkah demi langkah secara pasti dalam menyelesaikan suatu aktivitas, atau metode langkah demi langkah secara pasti dalam memecahkan suatu masalah. Data perbedaan jumlah stock aktual dengan data pada sistem tersebut dapat dilihat pada Grafik berikut ini.

\section{Hasil perbedaan stock produk consumable part \\ periode Januari - April 2019}

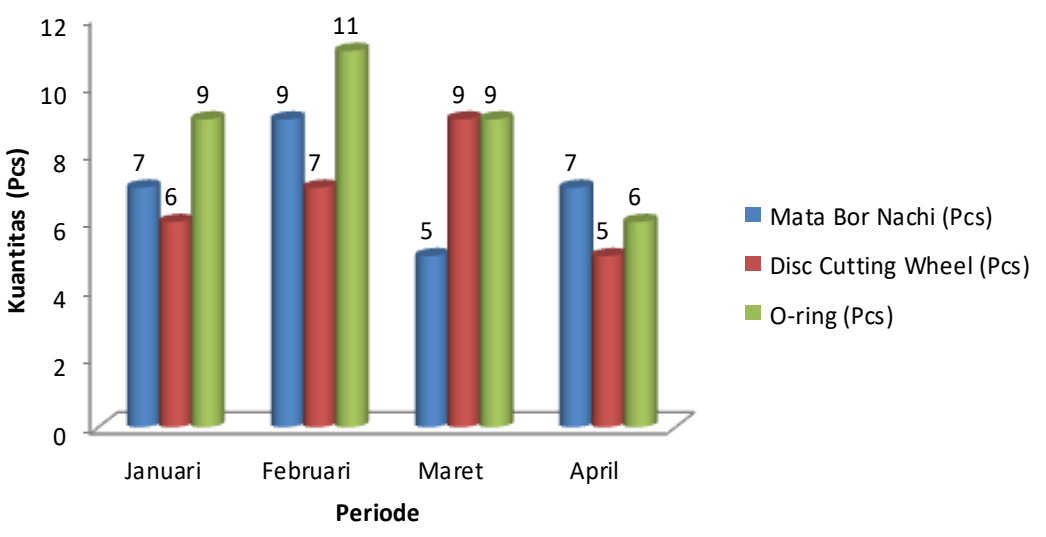

Gambar 1. Hasil perbedaan stock

Pada Grafik 1 merupakan data jumlah selisih stock aktual spare part dengan data pada sistem untuk spare part dengan type consumable part karena type ini merupakan spare part yang rutin digunakan seperti, o-ring, disc cutting wheel dan mata bor nachi. Pada periode Januari sampai dengan April terdapat perbedaan jumlah stock aktual dengan sistem untuk spare part jenis mata bor nachi sebanyak 28 pcs, untuk disc cutting wheel sebanyak 27 pcs dan spare part dengan jenis o-ring sebanyak 35 pcs. Dengan adanya hal ini dampak yang terjadi yaitu para pekerja akan kesulitan dalam mencari spare part karena pada periode saat dilakukannya stock take, spare part tersebut tidak tersedia di lokasi yang sudah ditentukan dan dapat menyebabkan kehilangan spare part. Biaya kehilangan spare part untuk periode Januari sampai dengan April sebesar Rp2.051.875,00 Berdasarkan uraian di atas maka untuk menyelesaikan masalah ini dengan mencari sebab-akibat dengan fishbone diagram dan memberikan usulan perbaikan dengan menggunakan metode $5 \mathrm{~W}+1 \mathrm{H}$.

\section{KAJIAN PUSTAKA DAN HIPOTESIS}

Tahapan Penyusunan SOP menurut Sailendra (2015:55), tahapan penyusunan SOP diuraikan sebagai berikut.

1. Dapatkan informasi sebanyak mungkin mengenai proses kerja. Hal ini bisa dilakukan dengan cara berdiskusi dan melakukan interview dengan Kepala Departemen yang sedang menjabat pada posisi yang akan dibuat SOP.

2. Catat efisiensi waktu, biaya, dan hal penting lainnya untuk kemungkinan sistem yang akan digunakan. 
3. Lakukan brainstorming terlebih dahulu untuk menerima pendapat dan masukan. Brainstorming bisa melibatkan staff, customer, dan pihak-pihak lain yang terlibat.

4. Buat terlebih dahulu draf baku untuk dilakukan pembahasan dengan tim.

5. Uji coba instrumen yang ada dengan draf SOP yang telah menjalani proses pembahasan.

6. Jika SOP dirasa sudah cukup efektif dan efisien, minta persetujuan pimpinan, setelah sebelumnya dibuat draf revisi final atas SOP tersebut.

7. Gunakan bahasa yang mudah dibaca, dipahami, dan dilaksanakan.

8. Tuliskan langkah demi langkah secara bertahap.

9. Gunakan kata kerja dalam kalimat aktif karena diharapkan pembaca melakukan sesuatu.

10. Gunakan kalimat positif dan hindari kata tidak dan jangan.

11. Buat bagan alurnya (flowchart).

12. Buat penjelasan yang dibutuhkan.

13. Buat dan cantumkan dokumen pendukung.

14. Cantumkan tanggal pembuatan SOP serta tanggal revisi.

15. Cantumkan petugas pembuat SOP dan siapa yang mengesahkan.

16. Cantumkan tanggal waktu pelaksanaan

\section{METODE PENELITIAN}

Berikut langkah-langkah dilakukan dalam penelitian ini:

1. Identifikasi Masalah

Mengidentifikasi masalah dengan dua tahap:

a. Data Primer

Merupakan data yang diperoleh langsung dari sumber datanya, berikut teknik pengumpulan:

1) Observasi dengan cara peninjauan langsung.

Sugiyono (2017), teknik pengumpulan data dengan observasi digunakan bila penelitian berkenaan dengan perilaku manusia, proses kerja, gejala-gejala alam dan bila responden yang diamati tidak terlalu besar.

2) Wawancara

Sailendra (2015), wawancara dilakukan untuk memperoleh informasi yang lebih mendalam dari narasumber yang menguasai secara teknis mengenai proses kerja yang dilakukan.

3) Kuesioner

Sugiyono (2016), Kuesioner merupakan teknik pengumpulan data yang dilakukan dengan cara memberi seperangkat pertanyaan atau pernyataan tertulis kepada responden untuk dijawabnya. Untuk hasil kuesioner diolah dengan menggunakan metode skala likert menurut Djaali (2008) ialah skala yang dapat dipergunakan untuk mengukur sikap, pendapat, dan persepsi seseorang atau sekelompok orang tentan suatu gejala atau fenomena pendidikan.

b. Data Sekunder

Sekaran, Uma (2011), sumber data yang mengacu pada informasi yang dikumpulkan dari sumber yang telah ada. Sumber data sekunder adalah catatan atau dokumentasu perusahaan, sebagai berikut :

1) Data hasil stock take untuk periode bulan Januari sampai dengan bulan April 2019.

2) Standar Operating Procedure (SOP) pengeluaran spare part.

\section{Metode Analisis}

Berikut tahapan dari metode analisis :

a. Menganalisis proses pengeluaran spare part di gudang

b. Analisis perbandingan kondisi aktual dengan SOP pengeluaran spare part

c. Identifikasi permasalahan sebab - akibat menggunakan diagram fishbone. 
Menganalisis faktor-faktor yang mempengaruhi terhadap permasalahan perbedaan jumlah stock aktual dengan yang ada pada sistem. Ulkhaq (2016) Diagram sebab-akibat atau yang biasa disebut Fishbone Diagram adalah alat untuk mengidentifikasi berbagai sebab potensial dari satu efek atau masalah, dan menganalisis masalah tersebut melalui sesi brainstorming. Masalah akan dipecah menjadi sejumlah kategori yang berkaitan, mencakup manusia, material, mesin, prosedur, kebijakan, dan sebagainya. Berikut ini adalah langkah-langkah dalam mengerjakan diagram fishbone menurut Soejitro, P (2010) yaitu :

1) Membuat kerangka diagram fishbone.

2) Merumuskan masalah utama.

3) Mencari faktor-faktor utama.

4) Menemukan penyebab untuk kelompok penyebab masalah.

5) Langkah selanjutnya setelah masalah dan penyebab masalah diketahui, kita dapat menggambarkannya dalam diagram fishbone.

6) Analisis Usulan perbaikan pada PT QWERTY menggunakan metode $5 \mathrm{~W}+1 \mathrm{H}$.

Utami (2018) 5W + 1H pada dasarnya adalah suatu metode yang digunakan untuk melakukan investigasi dan penelitian terhadap masalah yang terjadi dalam proses produksi. Konsep ataupun metode $5 \mathrm{~W}+1 \mathrm{H}$ ini tentunya tidak hanya dapat digunakan dalam proses produksi. Saat ini penelitian-penelitian, investigasi simbol ataupun jurnalisme juga menggunakan metode $5 \mathrm{~W}+1 \mathrm{H}$ untuk mengumpulkan informasi. Menurut Gaspersz,V (2002) adapun tahap improvement pada ini yaitu :

1) What, apa yang menjadi target utama dari perbaikan?

2) Why, mengapa rencana tindakan diperlukan?

3) Where, dimana rencana tindakan akan dilakukan?

4) Who, siapa yang akan mengerjakan aktivitas rencana tersebut?

5) When, kapan tindakan ini akan dilaksanakan?

6) How, bagaimana mengerjakan rencana tersebut?

\section{HASIL DAN PEMBAHASAN}

1. Analisis Proses Pengeluaran Spare part

Berikut merupakan alur kerja proses kerja pengeluaran spare part yaitu :

a. Menerima Technical Job Order (TJO) // Bukti Permintaan Barang (BPB) dari engineering/maintenance/user

Pada proses ini admin gudang menerima dokumen TJO (Technical Job Order) dari user area yang di dalam dokumen tersebut sudah terdapat kode dan deskripsi atau nama spare part yang dibutuhkan oleh user, selain TJO admin gudang juga menerima permintaan barang dengan menggunakan form BPB manual (Bukti Permintaan Barang), form BPB (Bukti Permintaan Barang) akan dibuatkan oleh admin gudang atau picker apabila user tidak menggunakan dokumen TJO untuk permintaan spare part.

b. Pengecekan Stock Spare part

Setelah admin gudang menerima dokumen TJO, kemudian checker akan melakukan pengecekan stock pada database yang ada di microsoft excel, untuk pengecekan stock dapat dicari dengan memasukan kode atau deskripsi yang terdapat pada dokumen Technical Job Order (TJO) kemudian dapat melakukan pengecekan fisik barang dengan melihat lokasi penyimpanan spare part sesuai dengan yang ada pada database.

c. Mengirimkan / Menyerahkan spare part ke user \& melakukan Good Issue

Pada proses ini apabila stock spare part tersedia di gudang maka spare part tersebut akan diserahkan kepada user sesuai dengan jumlah yang dibutuhkan oleh user, kemudian akan 
dilakukan pencatatan manual pada form BPB (Bukti Permintaan Barang) oleh admin gudang atau picker, form BPB tersebut ditandatangani oleh user, petugas gudang dan manager gudang. Form BPB berupa rangkap 3 lembar untuk lembar pertama diserahkan ke bagian accounting, untuk lembar yang kedua diserahkan kepada user dan untuk file di gudang menggunakan lembar yang ketiga. Proses selanjutnya admin gudang akan melakukan pembuatan Good Issue pada sistem SAP apabila form BPB sudah ditandatangani oleh pihak terkait dan user menyerahkan dokumen TJO.

d. Membuat PR ( Purchase Requisition)

Apabila stock di gudang tidak tersedia maka user melakukan permintaan kepada admin gudang untuk segera membuat PR (Purchase Requisition) melalui email dengan memberikan nomor TJO (Technical Job Order) dan spare part serta quantity untuk dibuatkan PR. Admin gudang akan mengecek quantity on hand, jika quantity on hand $=0$ maka akan dibuatkan sesuai dengan permintaan, kemudian admin gudang akan menyerahkan dokumen PR (Purchase Requisition) ke beberapa pihak yang terkait untuk menyetujui permintaan spare part dari user. Apabila quantity on hand pada gudang masih terdapat stock maka dokumen PR akan dibuatkan tetapi tidak dengan quantity yang sesuai dengan permintaan dari user.

2. Analisis perbandingan kondisi aktual dengan SOP pengeluaran spare part di industri manufaktur. Pada kondisi aktual proses pengeluaran spare part terdapat beberapa ketidaksesuaian dengan SOP. Beberapa aktivitas yang tercantum pada SOP tidak dilaksanakan oleh pekerja gudang dengan baik. Berikut aktivitas yang tidak dijalankan pada proses pengeluaran.

a. Menerima Technical Job Order (TJO) // Bukti Permintaan Barang (BPB) dari engineering/ maintenance / user.

Maintenance / user Pada SOP aktivitas yang dilakukan yaitu admin gudang menerima TJO (Technical Job Order) dari user, tetapi pada aktivitas aktualnya admin gudang tidak menerima dokumen tersebut dalam melakukan permintaan spare part, hal tersebut disebabkan karena user tidak mengetahui kode spare part yang jelas dan user hanya membawa spare part bekas sebagai contoh spare part yang dibutuhkan. Hal tersebut akan menyebabkan proses pencarian spare part membutuhkan waktu yang lama karena jenis dan kode dari spare part tersebut tidak diketahui sehingga akan berdampak pada proses produksi yang sedang berjalan.

b. Menyerahkan spare part \& tidak melakukan Good Issue

Pada SOP untuk proses ini petugas gudang menyerahkan spare part kepada user dan melakukan Good Issue. Namun, pada kegiatan aktualnya petugas gudang hanya menyerahkan spare part dan tidak melakukan Good Issue, tetapi petugas gudang hanya membuatkan form BPB (Bukti Permintaan Barang) secara manual dan akan melakukan Good Issue apabila form bukti permintaan barang sudah ditandatangani oleh beberapa pihak.

Hal tersebut disebabkan karena proses pembuatan Good Issue memerlukan nomor dokumen TJO dari user yang dibuat di dalam sistem, sehingga akan membutuhkan waktu 2 sampai 3 hari dalam pembuatan Good Issue. Dampak yang terjadi yaitu terdapat beberapa spare part yang sudah dikeluarkan dan belum dimasukkan ke dalam sistem SAP oleh admin gudang.

3. Identifikasi permasalahan sebab - akibat menggunakan diagram fishbone.

Berdasarkan permasalahan yang terjadi terdapat langkah untuk melakukan pemecahan masalah yaitu dengan menggunakan diagram fishbone. Dengan menggunakan diagram fishbone dapat ditemukan akar masalah atau penyebab dari suatu permasalahan yang terjadi pada perbedaan jumlah stock aktual dengan sistem dan untuk menentukan penyebab potensial didapatkan berdasarkan hasil kuesioner. Berikut ini adalah diagram fishbone beserta penjelasannya yang bertujuan untuk mencari dan menentukan penyebab masalah dari faktor yang di amati. 


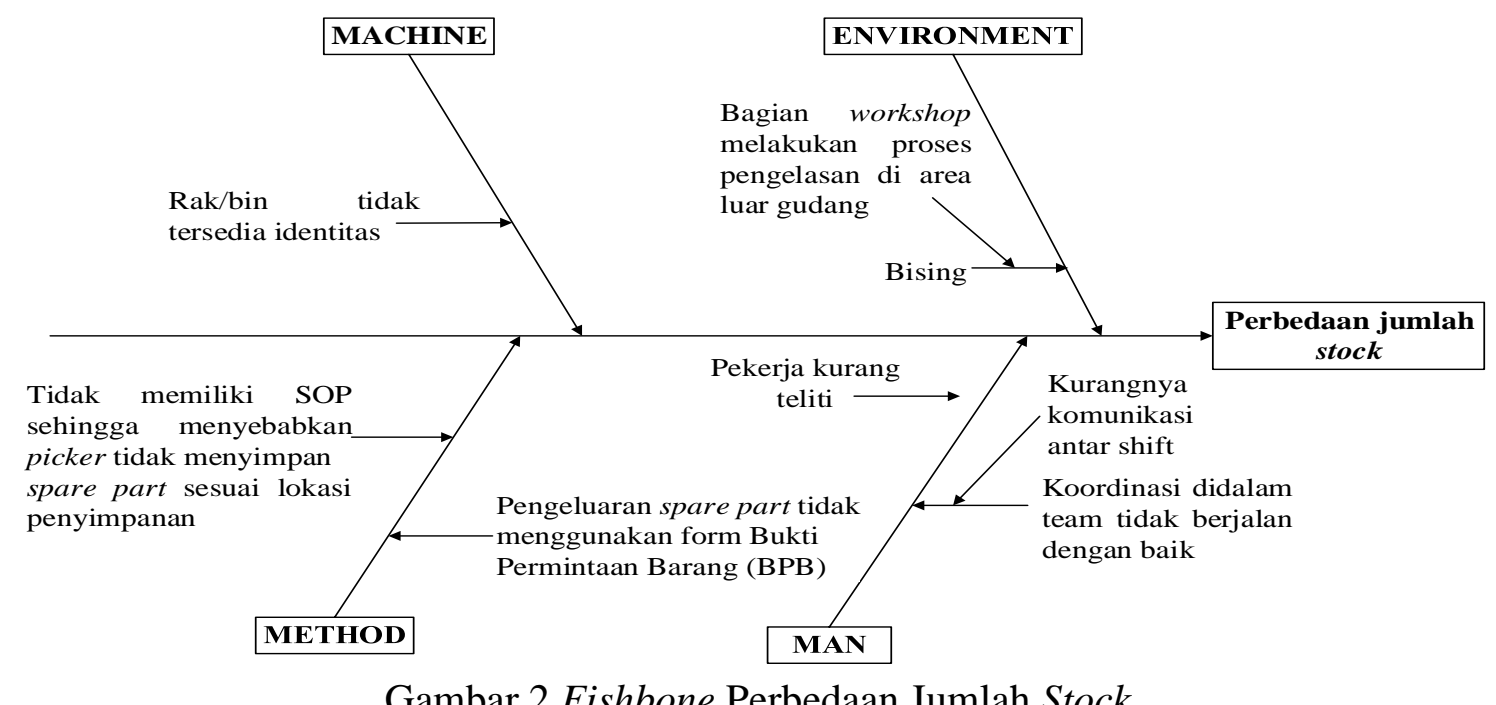

Berdasarkan Gambar 2 mengenai fishbone perbedaan jumlah stock aktual dengan data pada sistem, ditemukan beberapa penyebab terjadinya perbedaan jumlah stock aktual dengan sistem. Penyebab tersebut dikategorikan ke dalam empat faktor antara lain Man, Method, Machine dan Environment, sebagai berikut:

\section{Man}

Pada permasalahan perbedaan jumlah stock aktual dengan sistem pada gudang spare part disebabkan faktor man atau manusia antara lain yaitu pekerja kurang teliti dan koordinasi dalam team tidak berjalan dengan baik. Penyebab pekerja kurang teliti karena pada saat proses perhitungan jumlah stock untuk jenis spare part yang memiliki ukuran yang kecil dengan jumlah yang banyak seperti o-ring, karena tidak melakukan pengecekan ulang terhadap jumlah stock yang sudah dihitung dan pekerja yang terlibat dalam aktivitas tersebut hanya 1 pekerja yaitu checker. Penyebab selanjutnya yaitu koordinasi di dalam team tidak berjalan dengan baik yang disebabkan oleh pekerja yang bekerja pada shift $2 \& 3$ apabila telah melakukan pengeluaran spare part tidak memberikan informasi kepada pekerja shift 1 sehingga terdapat spare part yang telah dikeluarkan dan tidak dicatat pada form bukti permintaan barang.

\section{Method}

Perbedaan jumlah stock aktual dengan sistem terjadi karena faktor metode kerja yang masih belum baik. Penyebab terjadinya perbedaan jumlah stock aktual dengan sistem yaitu tidak adanya Standard Operating Procedure (SOP) untuk proses penyimpanan sehingga checker tidak menyimpan spare part sesuai bin dan rak yang telah ditentukan, hal itu akan menyulitkan pada saat proses stock take atau stock opname karena spare part tersebut tidak tersedia dan menyebabkan selisih jumlah stock. Penyebab kedua pada faktor method yaitu pengeluaran spare part tidak menggunakan form bukti permintaan barang (BPB), di dalam SOP seharusnya pengeluaran spare part harus menggunakan dokumen TJO apabila tidak menggunakan TJO maka petugas gudang akan membuatkan form BPB tetapi seringkali petugas gudang tidak melaksanakan prosedur kerja tersebut sesuai dengan SOP sehingga terdapat beberapa spare part tidak diinput kedalam sistem.

\section{Environment}

Faktor environment atau lingkungan juga disebabkan oleh kebisingan karena gudang spare part bersebelahan dengan bagian workshop sehingga pada saat ada proses pengelasan besi yang dilakukan di area luar workshop dan pekerja gudang merasa terganggu dan kurang serius saat 
melakukan proses pengecekan stock aktual.

\section{Machine}

Faktor machine merupakan fasilitas yang ada di gudang pada faktor machine yang menyebabkan perbedaan jumlah stock aktual dengan sistem yaitu karena terdapat beberapa bin tidak tersedia identitas dari masing-masing spare part yang disimpan, hal tersebut akan menyulitkan pekerja gudang dalam proses pencarian dan pengambilan spare part terutama pada saat melakukan pengecekan stock dan akan membutuhkan waktu yang lama.

Kesimpulan untuk faktor penyebab yang potensial berdasarkan hasil kuesioner terhadap permasalahan yang terjadi yaitu perbedaan jumlah stock aktual dengan sistem dan akar penyebab potensial mengacu pada faktor method disebabkan karena tidak adanya SOP untuk proses penyimpanan sehingga checker tidak melakukan proses penyimpanan spare part sesuai lokasi yang sudah ditentukan. Faktor penyebab selanjutnya yaitu faktor machine, disebabkan karena disetiap bin tidak tersedia atau tidak memiliki identitas dari masing-masing spare part yang disimpan sehingga checker dan checker akan kesulitan dalam mencari spare part tersebut. Berikut merupakan hasil rekapan dari kuesioner :

Tabel 1 Keterangan Kuesioner

\begin{tabular}{c|l}
\hline Variabel & \multicolumn{1}{|c}{ Keterangan } \\
\hline X1 & Rak/bin tidak tersedia identitas. \\
X2 & Tidak memiliki SOP sehingga menyebabkan picker tidak \\
& menyimpan Spare part sesuai lokasi penyimpanan \\
X3 & Pengeluaran spare part tidak menggunakan form Bukti \\
X4 & Permintaan Barang (BPB) \\
X5 & Pekerja kurang teliti \\
X6 & Koordinasi di dalam team tidak berjalan dengan baik \\
\hline
\end{tabular}

Tabel 1 merupakan keterangan kuesioner dengan akar penyebab dari permasalahan perbedaan jumlah stock aktual dengan sistem yang disimbolkan dengan variabel X yaitu X1, X2, X3, X4, X5 dan X6. Variabel tersebut disesuaikan dengan akar penyebab yang ada pada diagram fishbone dan berikut merupakan hasil rekapan kuesioner untuk menentukan akar penyebab yang paling potensial :

\section{Rekapan Kuesioner}

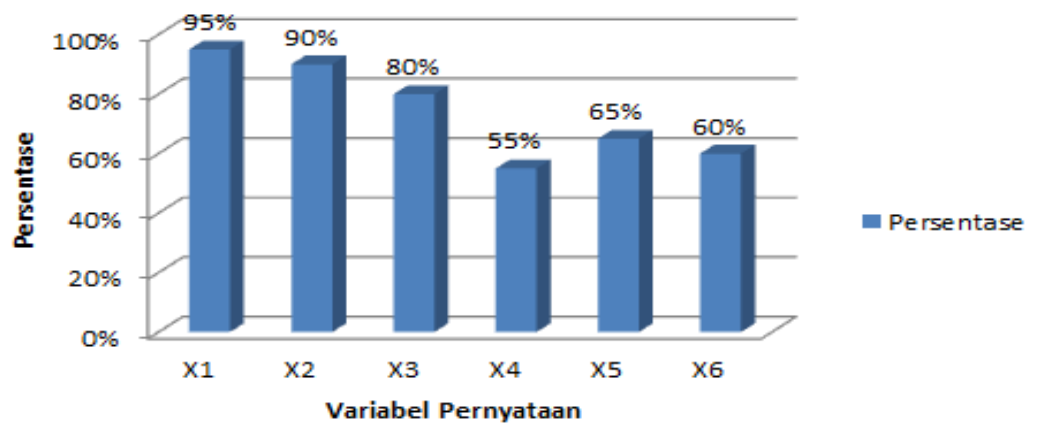

Grafik 3 Rekapan Hasil Kuesioner

Pada Grafik 3 merupakan rekapan hasil kuesioner yang sudah diisi oleh responden dengan jumlah responden sebanyak lima, pada hasil rekapan untuk variabel X1 dengan pernyataan rak/bin tidak tersedia identitas dengan jumlah persentase yang didapat sebesar 95\%. X2 dengan pernyataan tidak memiliki SOP sehingga menyebabkan picker tidak menyimpan spare part sesuai lokasi penyimpanan 
dengan persesntase sebesar 90\%, X3 dengan pernyataan pengeluaran spare part tidak menggunakan form Bukti Permintaan Barang (BPB) dengan jumlah hasil persentase sebesar 80\%, variabel X4 yaitu pekerja kurang teliti dengan persentase sebesar 55\%, X5 sebesar 65\% dengan pernyataan koordinasi di dalam team tidak berjalan dengan baik dan untuk X6 dengan pernyataan bising dengan persentase sebesar $60 \%$.

Dari hasil rekapan kuesioner mengenai permasalahan yang ada yaitu perbedaan jumlah stock aktual dengan sistem didapatkan penyebab potensial yang akan dijadikan usulan perbaikan. Berikut adalah usulan perbaikan menggunakan $5 \mathrm{~W}+1 \mathrm{H}$ dengan penyebab potensial berdasarkan hasil kuesioner dengan memprioritaskan 2 hasil persentase yang paling tinggi yaitu faktor method dengan akar penyebab yaitu tidak adanya SOP penyimpanan dengan persentase sebesar $95 \%$ dan faktor machine yaitu tidak adanya identitas pada bin/tempat penyimpanan dengan persentase sebesar $90 \%$ :

1. Apa yang menjadi target usulan perbaikan?

a. Merancang SOP pada proses penyimpanan spare part di gudang. Berikut merupakan langkah - langkah yang dilakukan dalam merancang Standard Operating Procedure (SOP) penyimpanan yaitu :

1) Memperoleh informasi mengenai aktivitas penyimpanan dengan cara diskusi dengan supervisor gudang dan petugas gudang spare part.

2) Setiap aktivitas dituliskan secara bertahap.

3) Mencantumkan dokumen pendukung seperti dokumen Good Receipt dan form checklist penyimpanan spare part.

4) Mencantumkan tanggal pembuatan SOP serta revisi yang dilakukan.

5) Mencantumkan petugas pembuat SOP dan siapa yang mengesahkan. 


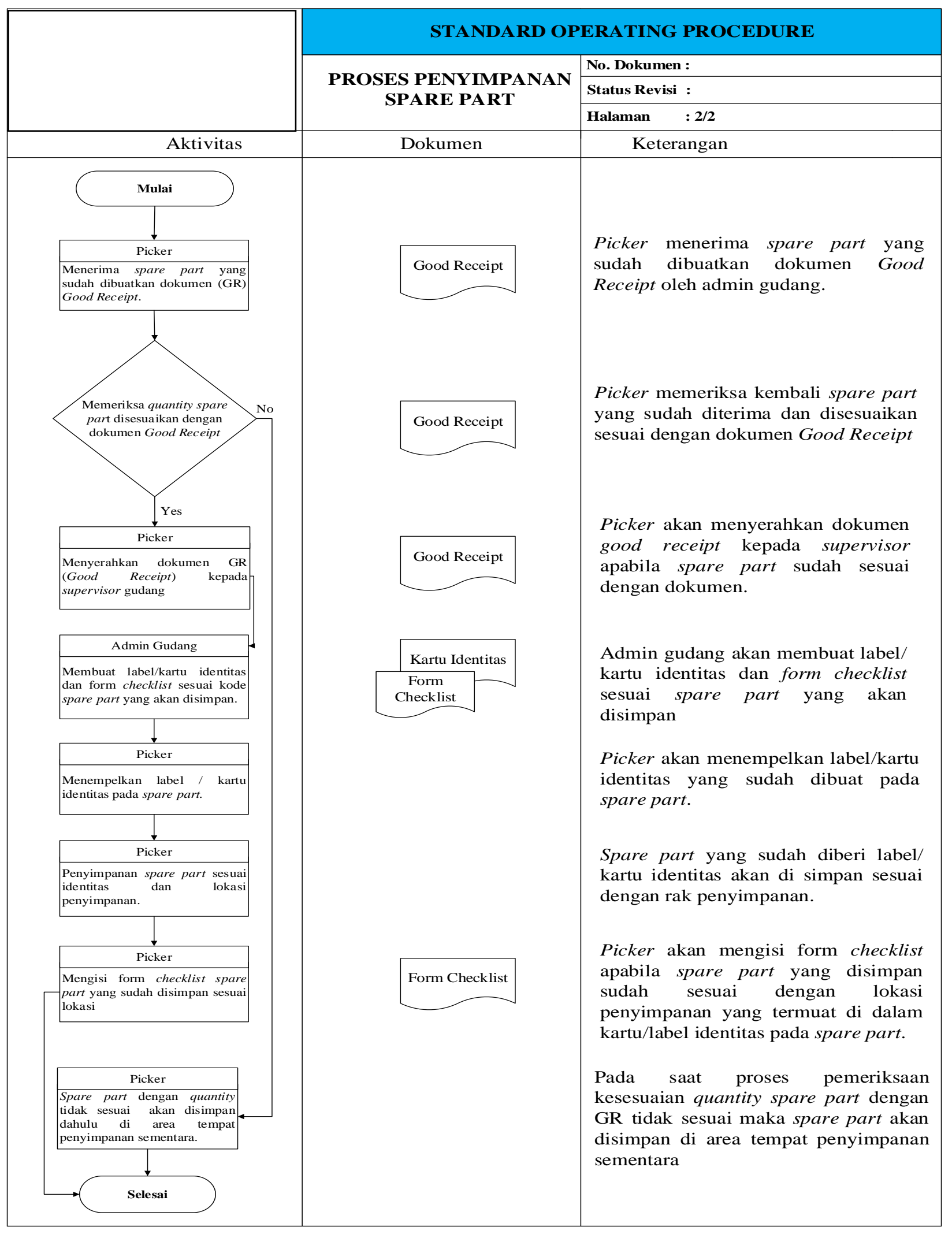

Gambar 4. Usulan Prosedur Kerja Penyimpanan 
2. Mengapa rencana tindakan itu diperlukan?

a. Karena gudang spare part belum memiliki SOP untuk proses penyimpanan spare part. Sehingga akan diusulkan mengenai rancangan SOP penyimpanan.

b. Karena setiap bin/box yang digunakan untuk menyimpan spare part belum memiliki identitas yang jelas, seperti kode dan nama dari spare part yang disimpan.

c. Karena pada saat proses pengecekan stock aktual dengan sistem sering mengalami perbedaan jumlah stock.

d. Karena petugas gudang kurang memahami dalam penerapan prosedur kerja yang baik.

3. Dimana rencana tindakan akan dilakukan?

a. Untuk rancangan SOP akan diusulkan untuk bagian gudang spare part khususnya untuk prosedur penyimpanan spare part.

b. Untuk pemberian identitas pada bin/box tempat menyimpan spare part akan dilakukan di area rak penyimpanan spare part di gudang

4. Kapan rencana itu akan dilakukan?

a. Untuk usulan SOP dapat diterapkan pada saat pihak gudang menyetujui mengenai usulan yang diberikan.

b. Pembuatan identitas dan melakukan penempelan pada bin penyimpanan dapat dilaksanakan dalam waktu 2 bulan.

5. Siapa yang akan mengerjakan?

Dikerjakan oleh pihak terkait yaitu supervisor gudang, picker, checker dan admin gudang. Picker dan checker memberikan identitas pada bin penyimpanan, admin gudang melakukan pembuatan identitas.

6. Bagaimana mengerjakan aktivitas rencana tindakan perbaikan?

a. Untuk prosedur kerja penyimpanan spare part dilakukan dengan membuat rancangan Standard Operating Procedure (SOP) mengenai penyimpanan spare part

b. Membuat identitas dengan informasi yang lengkap seperti kode spare part, nama spare part, type spare part dan lokasi penyimpanan, kemudian menempelkan identitas untuk di bin penyimpanan sesuai spare part yang disimpan.

c. Melakukan sosialisasi dengan melakukan penempelan prosedur kerja di area gudang spare part sehingga pekerja gudang lebih memahami aktivitas yang seharusnya dilakukan. Berikut merupakan simulasi dalam menempelkan prosedur kerja di area gudang spare part :

Dari usulan yang sudah diberikan kepada pihak gudang spare part dan supervisor gudang menerima mengenai usulan yang diberikan, tetapi supervisor akan melakukan pengajuan usulan kepada kepala gudang atau manager untuk melakukan perbaikan tersebut dengan melakukan revisi dengan beberapa pihak terkait.

\section{PENUTUP}

Berdasarkan pembahasan mengenai permasalahan yang ada yaitu perbedaan jumlah stock aktual dengan sistem di gudang spare part maka didapat kesimpulan sebagai berikut :

1) Terdapat beberapa faktor penyebab yang menyebabkan terjadinya ketidaksesuaian data Spare parts antara stock aktual dengan stock disistem dan dianalisis menggunakan diagram fishbone yaitu:

a. Faktor Man, disebabkan oleh koordinasi didalam team tidak berjalan dengan baik dan pekerja kurang teliti.

b. Faktor Method (metode), karena pada gudang spare part tidak memiliki Standard Operating Procedure (SOP) sehingga menyebabkan picker menyimpan spare part tidak disimpan 
sesuai dengan lokasi yang sudah ditentukan dan pengeluaran spare part tidak menggunakan form Bukti Permintaan Barang (BPB).

c. Faktor Environment, disebabkan karena kebisingan karena pada saat bagian workshop melakukan pengelasan dan prosesnya dilakukan di area luar yang bersebelahan dengan gudang spare part.

d. Faktor Machine, pada faktor machine ini karena rak/bin tidak memiliki identitas dari masing-masing spare part yang disimpan.

2) Usulan perbaikan ini adalah untuk meminimasi perbedaan jumlah stock aktual dengan sistem di gudang spare part dengan memberikan usulan berupa rancangan SOP untuk proses penyimpanan spare part dan memberikan identitas pada setiap bin sesuai dengan spare part yang disimpan.

\section{REFERENSI}

Djaali. 2008. Psikologi Pendidikan. Jakarta : Bumi Aksara

Fatimah, Fajar Nuraini. 2014. Pedoman Praktis Menyusun Standard Operating Procedure. Yogyakarta : Quadrant.

Gaspersz, V. 2002. Total Quality Management. Jakarta: PT Gramedia Pustaka Utama

Sailendra, Annie. 2015. Langkah-Langkah Praktis Membuat SOP. Yogyakarta: Trans Idea Publishing.

Sekaran, Uma. 2011. Metode Penelitian untuk Bisnis. Jakarta: Salemba Empat.

Soejitro, P. 2010. Instrumen Total Quality Management (TQM) sebagai pilihan alat pengendalian. Value Added: Majalah Ekonomi dan Bisnis.

Sugiyono, 2017. Metode Penelitian Kuantitatif, Kualitatif dan $R \& D$. Bandung : Alfabeta.

Ulkhaq, M. Mujya dan Rasyida, Dyah R. 2016. Aplikasi Seven Tools Dan Analisis 5w+1h Untuk Mengurangi Cacat Produk Galon: Studi Kasus Di PT. Berlina, Tbk. Jurnal Unisbank Semarang.

Utami, Rianti. 2018. Analisis Ketidaksesuaian Jumlah Stock Pipa uPVC pada PT Pralon Cimanggis. Jakarta : Politeknik APP Jakarta. 